\title{
ARCHEOFITONOK EXTENZÍV ALKALMAZÁSA
}

\section{EXTENSIVE APPLICATION OF ARCHAEOPHYTES}

\author{
Károly Ecseri ${ }^{1^{*}}$, Péter Honfi ${ }^{2}$ \\ ${ }^{1}$ Kertészeti Tanszék, Kertészeti és Vidékfejlesztési Kar, Neumann János Egyetem, Magyarország \\ 2 Dísznövénytermesztési és Dendrológiai Tanszék, Fenntartható Kertészet Intézet, Kertészettudományi Kar, \\ Szent István Egyetem, Magyarország \\ https://doi.org/10.47833/2021.1.AGR.002
}

\section{Kulcsszavak: \\ talajtakarás \\ díszítőérték \\ fenntarthatóság \\ vadvirágok \\ gyom}

\section{Keywords:}

soil covering

decoration value

sustainability

wildflowers

weed

\section{Cikktörténet:}

Beérkezett 2021. március 20.

Átdolgozva 2021. március 30.

Elfogadva 2021. április 5.

\begin{abstract}
Összefoglalás
A kutatásunkban az efemer szántóföldi vadvirágok fenntartási lehetőségeit vizsgáltuk kisparcellás kísérlet keretében. Ezen belül hangsúlyt fektettünk a talajtakaró-képességre, a díszitöértékre illetve a neofitonok megjelenésének mértékére. Ezen paraméterek detektálásával célunk volt a mesterségesen összeállított magkerevék létjogosultságát alátámasztani, valamint a fenntarthatóságát igazolni. Az eredményeink alapján megállapitható, hogy ez a zöldfelületi elem középtávon sikerrel alkalmazható, melyhez csupán éves szintü agrotechnikai beavatkozás szükséges.

Abstract
Continuation potential of ephemeral wildflowers was examined in
our research in a micro-plot experiment. Including this, we
focused on the soil cover capacity, the ornamental value and the
degree of neophytes appearance. We aimed to support the
viability of artificially constructed seed mixture as well as to prove
their sustainability by detecting these parameters. Based on our
results, it can be stated that this component of urban green space
can be successfully applied in the medium term, which requires
only an annual agrotechnical tillage.
\end{abstract}

\section{Introduction}

The urban green places in $21^{\text {th }}$ century follow a very clean (minimalist) style, moving towards unification and simple structure, using the mass of exotic woody and herbaceous taxa. At the same time garden designers are returning to the natural landscape for inspiration because of ecological crisis. Their goal is sustainable design and conservation of biodiversity. This natural state materializes in herbaceous vegetation in several European and American states [7]. Wildflower meadow with poppy and cornflower received the highest decorative value, according to opinion polling conducted in Germany. The most important aspects were the care and richness of color in the case of flowers [13]. The aesthetic garden is also characterized by naturalness and richness of species, according to the Swiss population, who like to use organic gardening but do not want a chaotic garden [12]. Several archaeophytes are among the most popular species: Agrostemma githago, Cyanus segetum, Papaver rhoeas [11].

Archaeophytes (so-called 'oldcomers') can be integrated into semi-natural gardens, as the properties of these green areas are closest to attributes of archaeophytes [20]. Due to simple propagation (or reproduction), [21] Consolida regalis, Cyanus segetum, or Papaver rhoeas are also

\footnotetext{
* Corresponding author. Tel.: +36-56-516-328

E-mail adress: ecseri.karoly@kvk.uni-neumann.hu
} 
preferred in peasant gardens [17]. Oldcomers (such as Malva sylvestris) can be well integrated into the concept of village gardens because of the multicolored flower carpet [2]. According to [3] the domesticated wildflowers from meadows are larkspur, pansy, cornflower, fumitory, mallow and poppy which are significant in folk culture not only because of their ornamental value but also their role in folk medicine. Moreover, Consolida regalis for example has long been used in home gardens [6]. It is recommended to use mixed planting as well as color mixtures during use [23]. They usually use in a millefleur flower beds [24] that provide quiet looking around on more intimate green surfaces (e.g. recreational areas) [18]. Homogenous patches of smaller species (e.g. Nigella arvensis) can be used in bed as filler plants, higher ones (e.g. Cyanus segetum) can be used as space shaping [4].

Another using possibility is wildflower meadows and seed mixtures. Consolida orientalis may be a conspicuous vertical element, but Malva sylvestris, Orlaya grandiflora and Papaver rhoeas are also recommended for use in flower meadows according to [14]. According to [25], in combination with grass species, the stock is sustainable, but for sufficient renewal it is necessary to disturb or rake the soil every year. Several companies distribute such products, such as Rieger-Hofmann $\mathrm{GmbH}$, which has a mixture of 14 archaeophytes in its wildflower mixture. Dominant species are Agrostemma githago and Cyanus segetum. The recommended amount is $2 \mathrm{~g} / \mathrm{m}^{2}$. Late autumn mowing is recommended during the maintenance.

An experimental wildflower border in Switzerland consisted of the following taxa: Achillea millefolium, Agrostemma githago, Centaurea jacea, Cichorium intybus, Cota tinctoria (syn. Anthemis tinctoria), Cyanus segetum, Daucus carota, Dipsacus fullonum, Echium vulgare, Hypericum perforatum, Leucanthemum vulgare, Malva moschata, Malva sylvestris, Origanum vulgare, Papaver rhoeas, Pastinaca sativa, Silene latifolia subsp. alba (syn. Silene pratensis), Tanacetum vulgare, Verbascum lychnitis, Verbascum thapsus [5]. Four of these species (Agrostemma githago, Cichorium intybus, Malva sylvestris, Papaver rhoeas) are also included in the Hungarian archaeophyte list.

It can be generally observed that Western European and American research focuses primarily on the analysis of perennial species, and there are few professional literatures on annual species. When seed mixtures are used, it can also be observed that therophyton species disappear already in the second vegetation due to the competitive effect of perennials [27]. But this is the only lifestyle group whose proportion increases as a result of urbanization [9], and its morphological, phenological and ecological parameters are also appropriate for urban use [1].

In addition, archeophytes can be used to green roadsides, slopes, and to decorate the disturbed surface of landfills, sand and gravel mines [15]. Recommended species for green roofs include Anthemis arvensis, Cyanus segetum, Consolida regalis and Papaver rhoeas [10]. A so-called R-strategy annual flower bed can be established from them in big cities. This application method is proposed, for example in the field of construction and renovation, as a green surface providing temporary covering and providing a natural effect. It can be established by the use of Orlaya grandiflora for example [19].

\section{Method}

The location of the experiment is a house garden; the soil is sandy poor in humus. The area was free of perennial weeds and was refilled with organic matter before to setting up the experiment. Sowing took place on 18 April 2013 on a smooth soil surface, shallowly incorporated and then irrigated. The sowed archaeophytes were as follows: Adonis aestivalis, Adonis flammea, Ajuga chamaepithys, Anthemis cotula, Consolida regalis, Cyanus segetum, Hibiscus trionum, Legousia speculum-veneris, Nigella arvensis, Malva sylvestris, Misopates orontium, Papaver rhoeas, Silene gallica, Sinapis arvensis, Stachys annua, Vaccaria hispanica, Vicia villosa. Total weight of seed mixture: $8329 \mathrm{mg}$.

The principle of species selection was that these belong to the same syntaxonomic class (Stellarietea mediae) [16], and the life form category of taxa, soil preference for soil reaction [22] and decorativeness were considered by [26]. 
Apart from the starting irrigation, the area was not watered. Agrotechnical procedure was performed only on 29 July 2014, 30 August 2016, 7 August 2017, 9 December 2018 and 27 July 2019 in the form of soil rotation. No organic matter was added or removed.

To increase the seed bank of the plot, $188 \mathrm{~g}$ (4273 seeds) of Vicia villosa were sown on 23 June 2013. (The number of seeds was calculated based on the thuosand-seed weight data of [8]). In addition, $0.4 \mathrm{~g}$ (200 seeds) of Cyanus segetum seeds were sowed on 30 August 2016 and Vaccaria hispanica seeds in $0.5 \mathrm{~g}$ (500 seeds) on 9 December 2018 and Fumaria officinalis $5.7 \mathrm{~g}$ (2800 seeds), Papaver dubium $0.9 \mathrm{~g}$ (15000 seeds), Sinapis arvensis $58.5 \mathrm{~g}$ (20100 seeds), Stachys annua $0.2 \mathrm{~g}$ (132 seeds), and Vaccaria hispanica $0.9 \mathrm{~g}$ (920 seeds) in 2019 on July 27.

Evaluation was performed two to three times a week during the period of intensive vegetative development and flowering, and once a week for the rest of the year, with bonitation (values between 0 and 5). Between 2013 and 2019, we documented the presence of each species, concentrating on the current phenophase (vegetative/generative). From 2015, we measured width and length parameters by species, from which we deduced the soil cover capacity.

\section{Results}

The studied taxa were divided into two groups based on soil cover capacity:

- $\quad$ species with large foliage (Cyanus segetum, Malva sylvestris, Papaver rhoeas, Sinapis arvensis, Vicia villosa)

- species with small foliage (Adonis aestivalis, Ajuga chamaepithys, Anthemis cotula, Consolida regalis, Hibiscus trionum, Nigella arvensis, Stachys annua, Vaccaria hispanica).

The grouping was based on the data in Table 1. which contains the average width and length data of the studied taxa between 2015 and 2019. Where these mean values were higher than $10 \mathrm{~cm}$ in at least $50 \%$ of the cases, the species was considered to have good soil cover properties and otherwise poor soil cover (data marked with a gray background).

The data show that Vicia villosa had the largest foliage area. Although we can't talk about real ground cover with this plant, as it climbs the other species with its tendrils. Weaker growth could be observed in the case of Papaver rhoeas in 2016 and Sinapis arvensis in 2017. The size of Vicia villosa decreased significantly in the last study year. Malva sylvestris showed more moderate horizontally growth in the 2017 and 2019 vegetation periods, respectively. Cyanus segetum data were the most balanced of the strong-growing taxa (Table 1).

The table also shows that taxa with small foliage area were present in the area only in 1-2 vegetation periods (e.g. Anthemis cotula, Consolida regalis, Hibiscus trionum, Nigella arvensis). Adonis aestivalis can also be classified in this group, but we were able to observe this species continuously between 2015 and 2018. Size data were balanced and the individuals could be considered very symmetrical.

Although Ajuga chamaepithys is slightly larger than the artificially formed $10 \mathrm{~cm}$ limit, it can still be classified as taxa with poor soil cover due to its leaf size and plant height. Although the horizontal dimension of Vaccaria hispanica can be considered small, it exceeds the other members of this category in leaf area and plant height. Table 1. does not include archaeophyton taxa that were not found in the original seed mixture. However, we observed the presence of Anagallis arvensis in 2015-16, as well as the spontaneous appearance of Viola arvensis (2016-17), Lamium amplexicaule and Lamium purpureum in the early spring aspect (2017-18). Each of these taxa is also an oldcomer plant.

Of the species with large foliage, Cyanus segetum and Papaver rhoeas were present in all study years. In addition, individuals of Malva sylvestris and Vaccaria hispanica were also observed throughout the 7-year cycle. Dominant amount was detected from cornflower in 2013 and from poppy between 2014-17.

Dominance relationships can be deduced from the length of presence of each species, also taking into account the data in Table 1. Among the strong-growing taxa Cyanus segetum, Malva sylvestris, Papaver rhoeas and Sinapis arvensis were also continuously present in the area in 2013 late spring-early summer and autumn aspects. Adonis aestivalis, Ajuga chamaepithys, Consolida 
regalis, Nigella arvensis and Stachys annua on the other hand, were observed only in the second half of the vegetation.

Table 1. Size of archaeophyte taxa in the 2015-2019 vegetation periods, in situ micro-plot study (Cegléd)

\begin{tabular}{|c|c|c|c|c|c|c|}
\hline Taxon name & Size $(\mathrm{cm})$ & 2015 & 2016 & 2017 & 2018 & 2019 \\
\hline \multirow{2}{*}{ Adonis aestivalis } & Width & 6.19 & 6.00 & 6.50 & 6.50 & \\
\hline & Length & 5.72 & 4.00 & 5.80 & 5.04 & \\
\hline \multirow{2}{*}{ Ajuga chamaepitys } & Width & 9.64 & 10.32 & & & 11.64 \\
\hline & Length & 10.91 & 10.04 & & & 11.18 \\
\hline \multirow{2}{*}{ Anthemis cotula } & Width & 8.00 & & 4.05 & & \\
\hline & Length & 9.26 & & 3.33 & & \\
\hline \multirow{2}{*}{ Consolida regalis } & Width & 3.07 & & & & \\
\hline & Length & 2.59 & & & & \\
\hline \multirow{2}{*}{ Cyanus segetum } & Width & 19.85 & 13.58 & 15.98 & 18.89 & 15.59 \\
\hline & Length & 17.26 & 13.34 & 14.72 & 13.75 & 13.93 \\
\hline \multirow{2}{*}{ Hibiscus trionum } & Width & & & & & 6.27 \\
\hline & Length & & & & & 5.27 \\
\hline \multirow{2}{*}{ Malva sylvestris } & Width & 25.33 & 22.43 & 16.18 & 28.02 & 13.17 \\
\hline & Length & 19.17 & 21.08 & 13.14 & 23.48 & 9.31 \\
\hline \multirow{2}{*}{ Nigella arvensis } & Width & 6.00 & 6.00 & & & \\
\hline & Length & 5.00 & 3.00 & & & \\
\hline \multirow{2}{*}{ Papaver rhoeas } & Width & 15.72 & 7.44 & 13.50 & 23.45 & 17.36 \\
\hline & Length & 14.55 & 6.85 & 12.07 & 20.20 & 17.19 \\
\hline \multirow{2}{*}{ Sinapis arvensis } & Width & 21.68 & 20.00 & 8.50 & & 21.50 \\
\hline & Length & 36.64 & 15.79 & 7.00 & & 20.50 \\
\hline \multirow{2}{*}{ Stachys annua } & Width & 7.39 & & 10.94 & 16.80 & 12.00 \\
\hline & Length & 8.42 & & 9.56 & 13.20 & 15.00 \\
\hline \multirow{2}{*}{ Vaccaria hispanica } & Width & 13.47 & 5.94 & 5.06 & 18.24 & 10.49 \\
\hline & Length & 9.68 & 4.00 & 3.94 & 17.48 & 9.37 \\
\hline \multirow{2}{*}{ Vicia villosa } & Width & 113.65 & 81.20 & 105.05 & 81.07 & 14.33 \\
\hline & Length & 75.82 & 18.60 & 83.43 & 14.80 & 7.27 \\
\hline
\end{tabular}

Note: Values marked with a gray background are less than $10 \mathrm{~cm}$.

In early spring 2014 Anthemis cotula, Cyanus segetum, Papaver rhoeas, Sinapis arvensis and Vaccaria hispanica germinated. Smaller species with weaker soil cover capacity only started to develop this year in late spring and early summer. At the turn of 2014-15, the rosettes of Papaver rhoeas and Sinapis arvensis were overwintered. In the third year of the study, specimens of Malva sylvestris began to develop very late (in the first decade of August). Germination of Sinapis arvensis and Vaccaria hispanica was also observed in the autumn aspect. Also in 2016, there was more diversity on the plot in the spring period, although seedlings of Cyanus segetum and Papaver rhoeas reappeared in the fall. Mallow was present in the area throughout the calendar year. In 2017, we observed again individuals of Anthemis cotula and Stachys annua. Together with them, 9 taxa were present for a longer or shorter period of this year. In the penultimate year, taxa with aggressive weedsuppressing ability (e.g. Cyanus segetum, Malva sylvestris) clearly dominated. At the end of 
assessment period (2019), several species reappeared in the autumn aspect (e.g. Hibiscus trionum, Stachys annua).

\section{Conclusion}

It can be concluded from the results that small-sized species with a weak soil cover value were quickly displaced from the area as they remained below in the competition for light. Archaeophytes with stronger rosettes, however become dominant as early as the first year of the experiment. The May-June period was the most diverse on the plot, when the decorative value of the area was also the most intense. The artificial association resulting from oldcomer species provided such effective soil cover that no significant neophyte gradation could be observed in any of the years. The key to sustainability is hidden in soil rotation at the optimal time.

\section{Acknowledgment}

Thank you for the support of EFOP-3.6.1-16-2016-00006 „Developing and expanding research potential at John von Neumann University" project. This project is supported by the Hungarian State and the European Union, co-financed by the European Social Fund, under the Széchenyi 2020 program.

\section{Literature}

[1] Bretzel, F., Vannucchi, F., Romano, D., Malorgio, F., Benvenuti, S., Pezzarossa, B. (2016): Wildflowers: From conserving biodiversity to urban greening - A review. Urban Forestry \& Urban Greening, 20. 428-436. p. https://doi.org/10.1016/j.ufug.2016.10.008

[2] Brookes, J. (1993): Apró kertek. [Tiny gardens]. Budapest: Officina Nova. 178, 212-213. p.

[3] Csoma Zs. (2015): Én kis kertet kerteltem... Paraszti virágkultúra Magyarországon. [I was gardening a small garden... Peasant flower culture in Hungary]. Budapest: Agroinform Kiadó. 63-66, 193-194. p.

[4] Győrffy A. (szerk.) (2007): Kertészkedők enciklopédiája. [Encyclopedia of gardeners]. Kína: Kossuth Kiadó zRt. 105, 197. p.

[5] Haaland, C., Gyllin, M. (2011): Sown Wildflower Strips - A Strategy to Enhance Biodiversity and Amenity in Intensively Used Agricultural Areas. 155-172. p. In: Lopez-Pujol, J. (ed.): The Importance of Biological Interactions in the Study of Biodiversity. Croatia: InTech. DOI: 10.5772/25076.

[6] Hessayon, D. G. (1996): Virágágyi dísznövények. [Flowerbed ornamental plants]. Budapest: Park Könyvkiadó. 36. p.

[7] Ignatieva, M. (2010): Design and Future of Urban Biodiversity. 118-144. p. In: Müller, N., Werner, P., Kelcey. J. (eds.): Urban Biodiversity and Design. Oxford: Blackwell Publishing Ltd. DOI: 10.1002/9781444318654.ch6

[8] Kebede, G., Assefa, G., Feyissa, F., Mengistu, A. (2016): Seed yield and yield components of vetch species and their accessions under nitosol and vertisol conditions in the central highlands of Ethiopia. International Journal of Development Research, 6 (7). 8692-8701. p.

[9] Klotz, S., Gutte, P. (1992): Biologisch-ökologische Daten zur Flora von Leipzig - ein Vergleich. Acta Academiae Scientiarum, 1. 94-97. p.

[10] Kumpfmüller, M. (2008): Wege zur Natur in kommunalen Freiräumen. Linz: Oberösterreichische Akademie für Umwelt und Natur. 227. $p$.

[11] Lindemann-Matthies, P., Bose, E. (2007): Species richness, structural diversity and species composition in meadows created by visitors of a botanical garden in Switzerland. Landscape and Urban Planning, 79. 298-307. p. https://doi.org/10.1016/j.landurbplan.2006.03.007

[12] Lindemann-Matthies, P., Marty, T. (2013): Does ecological gardening increase species richness and aesthetic quality of a garden? Biological Conservation, 159. 37-44. p. https://doi.org/10.1016/j.biocon.2012.12.011

[13] Lindemann-Matthies, P., Brieger, H. (2016): Does urban gardening increase aesthetic quality of urban areas? Urban Forestry and Urban Greening, 17. 33-41. p. https://doi.org/10.1016/j.ufug.2016.03.010

[14] Lord, T., Lawson, A. (2003): Harmonikus kertek enciklopédiája. [Encyclopedia of harmonious gardens]. Budapest: Kossuth Kiadó. 369, 386, 391-392. p.

[15] Meyer, S., Hilbig, W., Steffen, K., Schuch, S. (2013): Ackerwildkrautschutz - Eine Bibliographie. Bonn: Bundesamt für Naturschutz. 47. p.

[16] Mucina, L. (1993): Stellarietea mediae. 110-168. p. In: Mucina, L., Grabherr, G., Ellmauer, T. (herausgegeben): Die Pflanzengesellschaften Österreichs. Teil I. Anthropogene Vegetation. Jena: Gustav Fischer Verlag.

[17] Noordhuis, K. T. (2002): Kerti növények enciklopédiája. [Encyclopedia of garden plants]. Szlovénia: GABO Könyvkiadó. 279, 294. p.

[18] Ormos I. (1955): Kerttervezés története és gyakorlata. [History and practice of garden design]. Budapest: Mezőgazdasági Kiadó. 308. p. 
[19] Pápai V., Bíró B. (2016): Ökologikus zöldfelületek városi alkalmazása. [Urban application of ecological green spaces]. Budapest: Fökert Nonprofit Zrt. 50-55, 88, 90. p.

[20] Patkós I., Kovács E. (2018): Az évelö dísznövények felhasználása. [Use of perennial plants]. Budapest: Szerzői magánkiadás. 154-156. p.

[21] Schmidt G. (szerk.) (2003): Növények a kertépítészetben. [Plants in garden architecture]. Budapest: Mezőgazda Kiadó. 213-220. p.

[22] Simon T. (2000): A magyarországi edényes flóra határozója. [Vascular flora of Hungary]. Harasztok - virágos növények. [Ferns and flowering plants]. Budapest: Nemzeti Tankönyvkiadó. 892. p.

[23] Szántó M. (1982): Legszínesebbek az egynyári virágok. [The most colorful are the annual flowers]. p. 94-95. In: Lelkes L. (szerk.): Virágoskert, pihenőkert. [Flower garden, garden of rest]. Budapest: Mezőgazdasági Kiadó. 466. p.

[24] Throll, A. (2009): Kerti növények. Mi virít a kertben? [Garden plants. What blooms in the garden?]. Kaposvár: Sziget Könyvkiadó. 145, 161. p.

[25] Titchmarsh, A. (2005): Kertész leszek. A siker titkai. [I will be a gardener. Secrets of success]. Debrecen: Alexandra Kiadó. 271. p.

[26] Udvardy L. (2000): Archaikus gabonagyomjaink, mint dísznövények. [Our archaic grain weeds as ornamentals]. p. 415-419. In: Gyulai F. (szerk.): Az agrobiodiverzitás megőrzése és hasznositása, Szimpózium Jánossy Andor emlékére. [Preservation and utilization of agrobiodiversity, Symposium in memory of Andor Jánossy] Tápiószele: Agrobotanikai Intézet. 424. p.

[27] Vannucchi, F., Malorgio, F., Pezzarossa, B., Pini, R., Bretzel, F. (2014): Effects of compost and mowing on the productivity and density of a purpose-sown mixture of native herbaceous species to revegetate degraded soil in anthropized areas. Ecological Engineering, 74. 60-67. p. https://doi.org/10.1016/j.ecoleng.2014.09.121 